\title{
PERSISTENSI KINERJA REKSA DANA SAHAM DI BURSA EFEK INDONESIA
}

\begin{abstract}
Investors are required to be more prudent in determining the investment option since many choices For investing in a mutual funds are popped. So some research is needed to review the performance of mutual funds that active in Stock exchange to be a reference in predicting the performance of mutual funds next year.

This research use data from the beginning of the period 2007 until the end of 2012 or from the beginning of the global crisis period and during the crisis period is underway, it is expected to provide accurate results as a benchmark to invest in mutual funds. Because nowaday, the development of the capital markets is used by firms to raise funds from the public. The results of this study showed the presence of persistence in the performance of quarterly, semi annually, annually and biennial mutual fund shares at the Indonesia Stock Exchange. While the monthly and triennial performance of mutual fund shares in Indonesia Stock Exchange did not persistence.
\end{abstract}

Keywords: Performance Persistence of Mutual Fund Shares, mutual fund shares, mutual fund NAV, Jensen Model, Pearson Correlation .

\section{PENDAHULUAN}

Perkembangan pasar modal Indonesia dalam menggalang dana mempunyai peranan yang penting untuk menunjang pembangunan nasional. Dana masyarakat yang diperoleh dari pasar modal digunakan oleh banyak perusahaan lokal maupun perusahaan asing dengan tujuan bermacam-macam. Sedangkan bagi masyarakat pemodal kehadiran pasar modal merupakan tambahan alternatif pilihan untuk investasi ( Yuniawan, 2000).

Hingga saat ini perkembangan pasar modal sangat dimanfaatkan oleh para pelaku bisnis untuk menggalang dana dari publik. Dengan begitu perusahaan-perusahaan yang memanfaatkan pasar modal tidak akan terlalu kesulitan dalam pendanaan untuk mengembangkan bisnisnya. Pasar modal juga akan menjadi alternatif bagi para pemilik dana dimana pasar modal akan lebih banyak menyediakan pilihan dalam berinvestasi. Pilihan yang sebelumnya hanya ada pada obligasi dan saham saja, kini makin bertambah banyak. Mulai dari alternatif yang memiliki resiko rendah hingga yang mempunyai resiko paling tinggi.

Semakin banyaknya pilihan yang ditawarkan oleh pasar modal saat ini tidak serta merta hanya membawa kemudahan bagi para investor. Banyaknya pilihan tersebut secara tidak langsung mengharuskan para investor untuk berbuat jauh lebih jeli dan cerdas dalam memilih bentuk investasi dalam pasar modal. Dengan kata lain investor diharapkan tidak hanya memiliki kemampuan yang bagus dalam perhitungan prediksi seberapa bagus, tetapi lebih dari itu.

Naluri bisnis, pengalaman, serta pengetahuan yang cukup mengenai efek mana yang akan dibeli, efek mana yang akan dijual, dan efek mana yang akan dipertahankan hingga instrumen mana yang akan dipergunakan rasanya sangat perlu dimiliki oleh para investor yang akan melakukan investasi. Karena pada 
dasarnya investasi itu dibagi menjadi dua. (1) investasi secara langsung, yaitu dimana para investor melakukan kegiatan jual beli saham di pasar modal dengan melibatkan dirinya secara penuh tanpa melalui pihak perantara atau manajer investasi. (2) investasi secara tidak langsung, yaitu dimana para investor melakukan investasi melalui manajer keuangan atau dengan kata lain para investor tidak terlibat secara penuh dalam pelaksanaan investasi.

Baik secara langsung ataupun tidak langsung pada dasarnya investor harus memliki naluri bisnis, pengalaman, dan pengetahuan yang cukup mengenai pasar modal. Namun bagi para investor yang tidak memiliki kemampuan tersebut dapat melakukan investasi pada Reksa Dana. Reksa dana termasuk kedalam investasi secara tidak langsung karena dana yang dikelola merupakan dana kolektif yang dikumpulkan oleh manajer keuangan yang kemudian didiversifikasi kedalam berbagai bentuk portofolio efek. Tetapi menurut Simforianus dan Yanthi Hutagaol (2007) menjadi sebuah kesulitan bagi masyarakat awam untuk menentukan produk reksa dana mana yang dipilih. Pilihan jenis reksa dana sudah seperti sebuah pasar swalayan investasi.

Dari yang dipaparkan di atas, berarti para manajer investasi memerlukan informasi-informasi yang memiliki persistensi. Dalam arti bahwa informasi tersebut harus menenjukkan bahwa kinerja reksa dana yang baik tidak hanya dalam satu periode akuntansi atau satu tahun. Dengan begitu dapat diharapkan kinerja reksadana-reksadana tersebut akan berjalan baik di periode berikutnya. Apalagi dalam keadaan ekonomi dunia yang sekarang tengah dilanda krisis khususnya di negara-negara Eropa dan Amerika. Dengan keadaan seperti itu, Indonesia sebagai negara yang mampu mempertahankan pertumbuhan ekonominya di tengah krisis global, masih adakah persistensi pada kinerja reksa dana saham yang terdaftar di Bursa Efek Indonesia?

\section{KAJIAN PUSTAKA DAN PENGEMBANGAN HIPOTESIS}

\section{Teori Agensi}

Teori agensi menunjukan adanya hubungan kerja antara pihak yang memberi wewenang (principal) yaitu investor dengan pihak peneriman wewenang (agents) yaitu manajer dalam bentuk kontrak kerja sama. Seperti pernyataan Jensen dan Meckling (1976) yang menjelaskan hubungan keagenan sebagai "agency relationship as a contract under which one or more person (the principals) engage another person (the agent) to perform some service on their behalf which involves delegating some decision making authority to the agent".

\section{Pengertian Reksa dana}

Menurut Raharjo (2004) yang juga dikutip oleh Ambarwati (2007), secara umum pengertian reksa dana adalah suatu kumpulan dana dari masyarakat, pihak pemodal atau pihak investor untuk kemudian dikelola oleh manajer investasi dan diinvestasikan pada berbagai jenis portofolio investasi efek atau produk keuangan lainnya. Dana yang terkumpul akan di atur oleh manajer investasi untuk selebihnya akan di investasikan delam bentuk portofolio efek. Keuntungan yang diperoleh berupa kenaikan nilai investasi masyarakat pemodal seiring dengan berjalannya waktu periode investasi. 


\section{Kinerja Reksa Dana}

Menurut Ambarwati (2007) kinerja reksa dana adalah suatu ukuran kemampuan kerja atau prestasi yang dicapai oleh manajer investasi yang diperhitungkan dari NAB per unit yang merupakan data pengamatan. Sedangkan menurut Wibowo (2005) Kinerja Reksa dana adalah suatu ukuran kemampuan kerja atau prestasi yang dicapai manajer investasi.

\section{Pengembangan Hipotesis}

Beberapa penelitian terdahulu mengenai persistensi kinerja reksa dana saham mengemukakan persistensi yang sangat kuat pada kinerja bulanan, 3 bulanan, dan 6 bulanan reksa dana saham. Seperti Waelan (2009) yang menggunakan data 76 reksa dana menemukan adanya persistensi pada kinerja reksa dana saham bulanan, 3 bulanan, dan 6 bulanan. Serta penelitian Dorms dan Walker (2001) yang menggunakan data reksa dana saham sebanyak 529 dari tahun 1977 sampai dengan 1996 menemukan adanya persistensi kinerja reksa dana saham untuk jangka pendek yaitu yang kurang dari satu tahun. Dengan demikian, penelitian ini mengajukan hipotesis sebagai berikut :

H1 : Kinerja bulanan reksa dana saham di Bursa Efek Indonesia mengalami persistensi.

H2: Kinerja tiga bulanan reksa dana saham di Bursa Efek Indonesia mengalami persistensi.

H3 : Kinerja enam bulanan reksa dana saham di Bursa Efek Indonesia mengalami persistensi.

H4: Kinerja satu tahunan reksa dana saham di Bursa Efek Indonesia mengalami persistensi.

Beberapa penelitian terdahulu ada yang menemukan bahwa tidak terdapat persistensi pada kinerja reksa dana saham pada jangka waktu lebih dari satu tahun, seperti penelitian Dorms dan walker (2001), Bauer, et. al. (2006), sedangkan Krueger dan Callaway menemukan persistensi yang sangat kecil pada reksa dana saham yang mereka teliti tahun 1995. Padahal reksa dana saham merupakan reksa dana yang memiliki jangka waktu yang cukup panjang dan biasanya lebih dari satu tahun. Jadi, dari paparan tersebut penelitian ini juga mengajukan hipotesis sebagai berikut:

H5 : Kinerja dua tahunan reksa dana saham di Bursa Efek Indonesia tidak mengalami persistensi.

H6: Kinerja tiga tahunan reksa dana saham di Bursa Efek Indonesia tidak mengalami persistensi.

\section{METODE PENELITIAN}

\section{Data dan Sampel}

Data yang digunakan dalam penelitian ini merupakan data sekunder. Data yang diperoleh merupakan data reksa dana yang beredar di BEI dengan periode penelitian 6 tahun. Dengan periode mulai 1 Januari 2007 sampai dengan 31 Desember 2012.

Data meliputi nilai aktiva bersih (NAB), pendapatan indeks harga saham gabungan (IHSG), dan suku bunga sertifikat Bank Indonesia (SBI). Untuk nilai aktiva bersih (NAB) reksa dana saham dapat diperoleh di website Bapepam yaitu www.bapepam.go.id. Data mengenai pendapatan indeks harga saham gabungan (IHSG) dapat diperoleh di Bursa Efek Indonesia (BEI). Dan data mengenai suku bunga sertifikat Bank Indonesia (SBI) dapat diperoleh di website Bank Indonesia yaitu www.bi.go.id. 


\section{Kinerja Reksa Dana}

Kinerja merupakan abnormal return reksa dana saham, dimana abnormal return bulanan, tiga bulanan, enam bulanan, dan tahunan di hitung menggunakan jensen model. Sedangkan untuk abnormal return dua tahunan dan tiga tahunan merupakan return return reksa dana saham dikurangi return pasar (waelan, 2009).

Seperti pada penelitian yang dilakukan oleh Christian de la Torre (2010) model yang pertama digunakan dalam penelitian ini untuk memperkirakan abnormal return dari reksa dana saham adalah Capital Asset Pricing Model (CAPM). Model CAPM dapat dinyatakan sebagai berikut :

$$
E(R p)-R f=\beta p[E(R m)-R f]
$$

Dimana $E(R i)$ - Rf adalah resiko premium dari aset portofolio, dan $E(R m)^{-} R f$ adalah return yang diharapkan diatas tingkat bebas resiko. Sedangkan $\beta$ i adalah

$$
\beta i=\frac{\operatorname{cov}\left(R^{i}, R^{m}\right)}{\sigma^{2}\left(R^{m}\right)}
$$

ditafsirkan sebagai risiko sistematis aset i. Penurunan dari CAPM untuk aplikasi empiris dan, lebih jauh lagi, untuk mengukur kinerja reksa dana dijelaskan dalam Jensen (1967), dan dapat dinyatakan dengan cara berikut:

$R_{P t}-R_{F t}=\alpha_{p}+\beta_{p}\left[R_{M t}-R_{F t}\right]+\varepsilon_{P t} \ldots \ldots$ (2)

Dimana ;

$\mathrm{R}_{\mathrm{pt}}=$ Return reksa dana p pada waktu $\mathrm{t}$

$\mathrm{R}_{\mathrm{Ft}}=$ Return bebas resiko pada waktu $\mathrm{t}$

$\mathrm{R}_{\mathrm{Mt}}=$ Return pasar pada waktu $\mathrm{t}$

$\varepsilon_{p t}=$ Error Term

Dengan alpha $(\alpha)$ mengukur excess return diatas return bebas resiko yang di sesuaikan terhadap risiko pasar (Christian de la Torre , 2010). Ketika alpha positif mengimplikasikan bahwa reksa dana memiliki kinerja yang positif atau baik, dan sebaliknya jika alpha negatif maka kinerja reksa dana saham adalah buruk atau negatif.

Suatu persistensi kinerja adalah sebuah keberlanjutan kinerja, dimana akan ada suatu keterkaitan dari kinerja reksa dana yang sebelum periode penelitian dan setelah periode penelitian. Dalam penelitian ini akan diestimasikan hubungan kinerja portofolio pada suatu periode terhadap periode berikutnya. Model korelasi tersebut dapat disimbolkan sebagai berikut :

$\rho\left(\mathrm{R}_{\mathrm{Kt}}, \mathrm{R}_{\mathrm{Kt}+1}\right)$

Dimana

$\rho \quad=$ koefisien korelasi

$\mathrm{R}_{\mathrm{Kt}} \quad=$ kinerja sejumlah $\mathrm{k}$ portofolio waktu $\mathrm{t}$.

$\mathrm{R}_{\mathrm{kt}-1}=$ kinerja sejumlah $\mathrm{k}$ portofolio waktu $\mathrm{t}+1$

Jika $\rho$ positif dan signifikan menandakan terdapat persistensi kinerja, dimana kinerja suatu periode 
berhubungan positif dengan kinerja berikutnya.

\section{Pengukuran Variabel}

1. Menghitung return bulanan masing-masing reksa dana saham:

$$
\mathrm{RPt}=(\mathrm{NABPt}-\mathrm{NABPt}-1) / \mathrm{NABPt}-1
$$

Dimana:

RPt $\quad=$ return reksa dana saham $p$ bulan $t$.

NABPt $=$ NAB reksa dana saham $p$ akhir bulan $t$

NABPt-1 = NAB reksa dana saham $p$ akhir bulan $\mathrm{t}-1$

2. Menghitung return bulanan investasi bebas risiko:

$\mathrm{RFt}=\mathrm{SBIt} / 12$

Dimana:

RFt $=$ Return investasi bebas risiko bulan $\mathrm{t}$.

SBIt = Suku bunga tahunan SBI bulan $\mathrm{t}$

3. Menghitung return bulanan pasar:

$$
\text { RMt }=(\text { IHSGt-IHSGt-1) / IHSGt-1 }
$$

dimana:

RMt $=$ Return pasar bulan $\mathrm{t}$

IHSGt = IHSG akhir bulan t

IHSGt-1 = IHSG akhir bulan t-1

Pengukuran variabel untuk data tiga bulanan, enam bulanan, tahunan, dua tahunan dan tiga tahunan menggunakan model-model di atas dengan menyesuaikan unsur waktunya.

\section{Teknik Analisis}

Pengujian hipotesis 1 (H1) akan menggunakan langkah-langkah sebagai berikut : Pertama, menghitung return bulanan untuk masing-masing reksa dana saham. Kedua, menghitung return bulanan investasi bebas resiko. Dan ketiga, menghitung return bulanan pasar. Kemudian melakukan mengestimasikan fungsi kinerja bulanan rekas dana saham menggunakan model (2) memakai data pooled mencakup semua reksa dana saham selama periode penelitian. Lalu menghitung kinerja bulanan masing-masing reksa dana saham berdasarkan fungsi kinerja yang didapat. Terakhir, menggunakan model (3) memakai data pooled menguji persistensi kinerja bulanan. Hipotesis 1 diterima jika $\rho$ menunjukan angka positif dan signifikan.

Pengujian hipotesis 2 (H2) akan menggunakan langkah-langkah sebagai berikut : Pertama, menghitung return tiga bulanan untuk masing-masing reksa dana saham. Kedua, menghitung return tiga bulanan investasi bebas resiko. Dan ketiga, menghitung return tiga bulanan pasar. Kemudian melakukan estimasi fungsi kinerja tiga bulanan reksa dana saham menggunakan model (2) memakai data pooled mencakup semua reksa dana saham selama periode penelitian. Lalu menghitung kinerja tiga bulanan masing-masing reksa dana saham berdasarkan fungsi kinerja yang didapat. Terakhir, menggunakan model (3) memakai data pooled menguji persistensi kinerja tiga bulanan. Hipotesis 2 diterima jika $\rho$ menunjukan angka positif dan signifikan. 
Pengujian hipotesis 3 (H3) akan menggunakan langkah-langkah sebagai berikut : Pertama, menghitung return enam bulanan untuk masing-masing reksa dana saham. Kedua, menghitung return enam bulanan investasi bebas resiko. Dan ketiga, menghitung return enam bulanan pasar. Kemudian melakukan mengestimasikan fungsi kinerja enam bulanan rekas dana saham menggunakan model (2) memakai data pooled mencakup semua reksa dana saham selama periode penelitian. Lalu menghitung kinerja enam bulanan masing-masing reksa dana saham berdasarkan fungsi kinerja yang didapat. Terakhir, menggunakan model (3) memakai data pooled menguji persistensi kinerja enam bulanan. Hipotesis 3 diterima jika $\rho$ menunjukan angka positif dan signifikan.

Pengujian hipotesis 4 (H4) akan menggunakan langkah-langkah sebagai berikut : Pertama, menghitung return tahunan untuk masing-masing reksa dana saham. Kedua, menghitung return tahunan investasi bebas resiko. Dan ketiga, menghitung return tahunan pasar. Kemudian melakukan mengestimasikan fungsi kinerja tahunan rekas dana saham menggunakan model (2) memakai data pooled mencakup semua reksa dana saham selama periode penelitian. Lalu menghitung kinerja tahunan masing-masing reksa dana saham berdasarkan fungsi kinerja yang didapat. Terakhir, menggunakan model (3) memakai data pooled menguji persistensi kinerja tahunan. Hipotesis 4 diterima jika $\rho$ menunjukan angka positif dan signifikan.

Pengujian hipotesis 5 (H5) akan menggunakan langkah-langkah sebagai berikut: Pertama, menghitung return dua tahunan untuk masing-masing reksa dana saham. Kedua, menghitung return dua tahunan pasar. Ketiga, menghitung kinerja dua tahunan masing-masing reksa dana saham dengan rumus kinerja adalah return reksa dana dikurangi return pasar. Kemudian menggunakan model (3) memakai data cross section, menguji persistensi kinerja dua tahun pertama dengan dua tahun kedua. Dan menguji persistensi kinerja dua tahun kedua dengan kinerja dua tahun ketiga menggunakan model (3) memakai data cross section. Hipotesis 5 diterima jika $\rho$ yang dihasilkan dari kedua uji persistensi tersebut menunjukan angka positif dan signifikan.

Pengujian hipotesis 6 (H6) akan menggunakan langkah-langkah sebagai berikut : Pertama, menghitung return tiga tahunan untuk masing-masing reksa dana saham. Kedua, menghitung return tiga tahunan pasar. Ketiga, menghitung kinerja tiga tahunan masing-masing reksa dana saham dengan rumus kinerja adalah return reksa dana dikurangi return pasar. Kemudian menggunakan model (3) memakai data cross section, menguji persistensi kinerja tiga tahun pertama dengan tiga tahun kedua. Hipotesis 6 diterima jika $\rho$ yang dihasilkan dari kedua uji persistensi tersebut menunjukan angka positif dan signifikan.

\section{HASIL DAN PEMBAHASAN}

\section{Presistensi kinerja reksadana satu bulanan}

Berdasarkan hasil perhitungan dengan menggunakan SPSS versi 16. diperoleh hasil signifikasi signifikasi untuk kinerja saham satu bulanan waktu t dengan kinerja saham satu bulanan waktu $t+1$ sebesar 0,397 dan nilai koefisien korelasi sebesar 0,024, hal ini dapat diartikan bahwa kinerja reksadana satu bulanan tidak mengalami presistensi, karena nilai signifikasi 0,397 >0,05. Dengan demikian hipotesis 1 ditolak, artinya kinerja reksadana satu bulanan tidak mengalami presistensi. 


\section{Presistensi kinerja reksadana tiga bulanan}

Berdasarkan hasil perhitungan dengan menggunakan SPSS versi 16. diperoleh hasil signifikasi signifikasi untuk kinerja saham tiga bulanan waktu $t$ dengan kinerja saham tiga bulanan waktu $\mathrm{t}+1$ sebesar 0,018 dan nilai koefisien korelasi sebesar 0,119 , hal ini dapat diartikan bahwa kinerja reksadana tiga bulanan mengalami presistensi, karena nilai signifikasi 0,018<0,05. Dengan demikian hipotesis 2 diterima, artinya kinerja reksadana tiga bulanan mengalami presistensi.

\section{Presistensi kinerja reksadana enam bulanan}

Berdasarkan hasil perhitungan dengan menggunakan SPSS versi 16. diperoleh hasil signifikasi signifikasi untuk kinerja saham enam bulanan waktu t dengan kinerja saham enam bulanan waktu $\mathrm{t}+1$ sebesar 0,029 dan nilai koefisien korelasi sebesar 0,176, hal ini dapat diartikan bahwa kinerja reksadana enam bulanan mengalami presistensi, karena nilai signifikasi 0,029 $<0,05$. Dengan demikian hipotesis 3 diterima, artinya kinerja reksadana enam bulanan mengalami presistensi.

\section{Presistensi kinerja reksadana satu tahunan}

Berdasarkan hasil perhitungan dengan menggunakan SPSS versi 16. diperoleh hasil signifikasi signifikasi untuk kinerja saham satu tahunan waktu t dengan kinerja saham satu tahunan waktu $\mathrm{t}+1$ sebesar 0,000 dan nilai koefisien korelasi sebesar 0,485, hal ini dapat diartikan bahwa kinerja reksadana satu tahunan mengalami presistensi, karena nilai signifikasi 0,000 <0,05. Dengan demikian hipotesis 4 diterima, artinya kinerja reksadana satu tahunan mengalami presistensi.

\section{Presistensi kinerja reksadana dua tahunan}

Berdasarkan hasil perhitungan dengan menggunakan SPSS versi 16. diperoleh hasil signifikasi signifikasi untuk kinerja saham dua tahunan waktu t dengan kinerja saham dua tahunan waktu $t+1$ sebesar 0,000 dan nilai koefisien korelasi sebesar 0,917, hal ini dapat diartikan bahwa kinerja reksadana dua tahunan mengalami presistensi, karena nilai signifikasi 0,000 <0,05. Dengan demikian hipotesis 5 ditolak, artinya kinerja reksadana dua tahunan mengalami presistensi.

\section{Presistensi kinerja reksadana tiga tahunan}

Berdasarkan hasil perhitungan dengan menggunakan SPSS versi 16. diperoleh hasil signifikasi signifikasi untuk kinerja saham tiga tahunan waktu t dengan kinerja saham tiga tahunan waktu $\mathrm{t}+1$ sebesar 0,804 dan nilai koefisien korelasi sebesar -0,065, hal ini dapat diartikan bahwa kinerja reksadana tiga tahunan tidak mengalami presistensi, karena nilai signifikasi 0,804 >0,05. Dengan demikian hipotesis 6 diterima, artinya kinerja reksadana tiga tahunan tidak mengalami presistensi.

\section{Pembahasan}

Kinerja reksadana satu bulanan tidak mengalami presistensi, karena nilai signifikasi 0,397 $>0,05$. Jika 
di lihat dari statistik deskriptif nilai rata-rata kinerja saham satu bulanan waktu t adalah sebesar -0,68234 lebih rendah dibandingkan dengan rata-rata kinerja saham satu bulanan waktu t+1 sebesar -0,068652. Hal ini mengindikasikan bahwa kinerja reksadana pada periode satu bulanan ke bulanan berikutnya tidak berkelanjutan. Hasil ini tidak mendukung penelitian Waelan (2009), Casarin dkk (2005), Hij dan Verbeek (2005).

Kinerja reksadana tiga bulanan mengalami presistensi, karena nilai signifikasi $0,018<0,05$. Jika di lihat dari statistik deskriptif nilai rata-rata kinerja nilai rata-rata kinerja saham tiga bulanan waktu t adalah sebesar $-0,0719$ lebih tinggi dibandingkan dengan rata-rata kinerja saham tiga bulanan tahun waktu $\mathrm{t}+1$ sebesar $-0,0403$. Hasil tersebut mengindikasikan bahwa kinerja reksadana pada periode tiga bulanan ke tiga bulanan berikutnya berkelanjutan. Hasil ini mendukung penelitian Cortez dkk (1999), Waelan (2009), serta Dorm dan Walker (2001).

Kinerja reksadana enam bulanan mengalami presistensi, karena nilai signifikasi $0,029<0,05$. Jika di lihat dari statistik deskriptif nilai rata-rata kinerja saham enam bulanan waktu t adalah sebesar -0,0582 lebih rendah dibandingkan dengan rata-rata kinerja saham enam bulanan waktu $t+1$ sebesar $-0,0593$. Hasil ini mendukung penelitian Bouer, dkk (2006) yang mengadakan penelitian tentang pengukuran kinerja dan presistensi kinerja reksadana dan memberikan hasil bahwa terdapat presistensi kinerja reksana untuk jangka waktu enam bulan. Hasil ini juga mendukung Sundavall (2006) yang juga memberikan bukti empiris bahwa terdapat presistensi kinerja reksana untuk jangka waktu enam bulan.

Kinerja reksadana satu tahunan mengalami presistensi, karena nilai signifikasi $0,000<0,05$. Jika di lihat dari statistik deskriptif nilai rata-rata kinerja saham satu tahunan waktu t adalah sebesar -0,0582 lebih rendah dibandingkan dengan rata-rata kinerja saham satu tahunan waktu $t+1$ sebesar $-0,0593$. Hasil ini mendukung penelitian Elton, dkk (1996), Walker (2001), serta penelitian Waelan (2009).

Kinerja reksadana dua tahunan mengalami presistensi, karena nilai signifikasi $0,000<0,05$. Jika di lihat dari statistik deskriptif nilai rata-rata kinerja saham dua tahunan waktu t adalah sebesar -0,0315 lebih tinggi dibandingkan dengan rata-rata kinerja saham dua tahunan waktu $t+1$ sebesar $-0,0314$. Hasil ini mendukung penelitian Elton, dkk (1996), Walker (2001), serta penelitian Waelan (2009).

\section{Kesimpulan}

Kinerja reksadana satu bulanan tidak mengalami presistensi, karena nilai signifikasi 0,397 $>0,05$. Kinerja reksadana tiga bulanan mengalami presistensi, karena nilai signifikasi 0,018<0,05. Kinerja reksadana enam bulanan mengalami presistensi, karena nilai signifikasi 0,029<0,05. Kinerja reksadana satu tahunan mengalami presistensi, karena nilai signifikasi $0,000<0,05$. Kinerja reksadana dua tahunan mengalami presistensi, karena nilai signifikasi $0,000<0,05$. Kinerja reksadana tiga tahunan tidak mengalami presistensi, karena nilai signifikasi $0,804>0,05$.

\section{Keterbatasan}

Beberapa keterbatasan dalam penelitian ini yang masih perlu menjadi bahan revisi penelitian selanjutnya, jumlah sampel adalah 17 reksa dana, sehingga masih relatif kecil. Selain itu faktor-faktor yang mempengaruhi 
adanya fluktuasi kinerja reksa dana saham belom di perhitungkan dalam penelitian ini, seperti faktor-faktor keadaan politik, kondisi perusahaan penyedia reksa dana saham, dan memperluas jenis reksa dana yang diteliti sehingga tidak hanya pada reksa dana saham saja

\section{Saran}

Berdasarkan hasil penelitian, maka saran yang diberikan adalah investor lebih memperhatikan kinerja reksa dana jangka waktu 3 bulanan, 6 bulanan, 1 tahunan dan 2 tahunan yang mengalami presistensi. Reksa dana mengalami presistensi dapat dartikan bahwa kinerja reksa dana berkelanjutan pada waktu 3 bulanan, 6 bulanan, 1 tahunan dan 2 tahunan, sehingga investor bisa memprediksi kinerja reksa dana tersebut.

\section{DAFTAR PUSTAKA}

Ambarwati. (2007). "Analisis Perbandingan Kinerja Reksa Dana Saham Dengan Kinerja Pasar (IHSG) Melalui Pendekatan Sharpe Dan Treynor". Tesis, MM UNDIP, Semarang.

Babalos, V. et. al. (2005). "Testing for persistence in mutual fund performance and the ex post veri.cation problem: Evidence from the Greek market". University of Piraeus, Yunani.

Budi, Teguh Pamungkas. (2001). "Analisis Portofolio Reksa Dana Saham Yang Optimal”. Tesis. MM UNDIP, Tidak Dipublikasikan, Semarang.

Casarin, R. et. al. (2005). "Relative Benchnark Rating and Persistence Analysis: Evidence from Italian Equity Funds". The European Journal of Finance.

Droms, W.G. dan Walker, D.A. (2001). "Performance Persistence of International Mutual Funds". Global Finance Journal.

Elton, E.J., Gruber, MJ. dan Blake, CR. (1996). "The Persistence of Risk- Adjusted Mutual Fund Performance", Journal of Business.

Grinblatt, M. dan Titman,S. (1992), "The Persistence of Mutual Fund Performance”, The Journal of Finance.

Hendricks, D., Patel, J. dan Zeckhauser, R. (1993). “Hot Hands in Mutual Funds: Short-Run Persistence of Relative Performance, 1974-1988", The Journal of Finance.

Yuniawan, Ade, (2000), “Penilaian Kinerja Portofolio Reksadana Saham Periode Juli - September 1999”, Tesis, MM UGM, Tidak Dipublikasikan, Yogyakarta.

Hutagaol, Yanthi., Simforianus, (2007), "Analisis Kinerja Reksa Dana Saham Dengan Metode Raw Return, Sharpe,

Treynor, Jensen Dan Sortino", Journal of Applied Finance and Accounting

Jensen, M., 1968, "The Performance of Mutual Funds in the Period 1945-1964," Journal of Finance.

Krueger, T.M. dan Callaway, R.E. (1995).“The Persistence of Three-Year Mutual Fund Performance”. Journal of

Financial Planning,

Pratomo, E.P., dan Ubaidillah N., 2002. "Reksa Dana Solusi Perencanaan Investasi di Era Modern”. Edisi Revisi. Cetakan Kedua, Gramedia Pustaka Utama, Jakarta.

Torre, Christian. (2010). "Mutual Fund Performance". Master Thesis. ULM University, Prancis. 


\section{JURNAL AKUNTANSI INDONESIA}

Veronika, Trisni Wulandari. (2004). “Analisis Kinerja Reksa Dana Saham Dan Reksa Dana Pasar Uang Dengan Metode Sharpe Periode Januari-Desember 2003". Tesis, MM UNDIP, Tidak Dipublikasikan, Semarang.

Vicente L. dan Ferrus, L. (2005), “Performance Persistence in Spanish Funds”. Applied Financial Economic, Vol. 15, Pages 1305-1313.

Waelan. (2007). “Persistensi Kinerja Reksa Dana Saham DI Bursa Efek Idonesia”. Jurnal Akuntansi Dan Auditing Indonesia

Waluyo, Eko. (2012). “Pengaruh Kinerja Keuangan Terhadap Return Saham Pada Emiten Sektor Pertanian Bursa Efek". Universitas Pendidikan Indonesia.

Yi, Ronghua., dan Ying Zhao. (2010). "Persistence in Mutual Fund Returns: Evidence From China”. International Journal of Business and Social Science

Jurnal Akuntansi Indonesia 
JURNAL AKUNTANSI INDONESIA

Tabel 1

\begin{tabular}{|c|c|c|}
\hline Nama Reksa Dana & Manajer Inestasi & Bank Kustodian \\
\hline Bahana Dana Prima & $\begin{array}{l}\text { PT. Bahana TCW Investment } \\
\text { Managemen }\end{array}$ & Deutsche Bank A.G-Custody \\
\hline BNI Dana Berkembang & PT. BNI Asset Management & CIMB Niaga-Custody \\
\hline Dana Ekuitas Andalan & $\begin{array}{l}\text { PT. Bahana TCW Investment } \\
\text { Managemen }\end{array}$ & Deutsche Bank A.G-Custody \\
\hline Danareksa Mawar & $\begin{array}{l}\text { PT. Danareksa Investment } \\
\text { Management }\end{array}$ & $\begin{array}{l}\text { PT. Danareksa Investment } \\
\text { Management }\end{array}$ \\
\hline FS Deviden Yield Fund & $\begin{array}{l}\text { PT. First State Investement } \\
\text { Indonesia }\end{array}$ & HSBC - Custody \\
\hline FS Indooequity Sectoral Fund & $\begin{array}{l}\text { PT. First State Investement } \\
\text { Indonesia }\end{array}$ & HSBC - Custody \\
\hline Makinta Mantap & PT. Emco Asset Management & CIMB Niaga-Custody \\
\hline Mandiri Investasi Atraktif & PT. Mandiri Manajemen Investasi & HSBC - Custody \\
\hline Manulife Dana Saham & $\begin{array}{l}\text { PT. Manulife Aset Manajemen } \\
\text { Indonesia }\end{array}$ & Deutsche Bank A.G - Custody \\
\hline Panin Dana Makasima & Panin Asset Management & Bank Central Asia - Custody \\
\hline Phinisi Dana Saham & $\begin{array}{l}\text { PT. Manulife Aset Manajemen } \\
\text { Indonesia }\end{array}$ & Deutsche Bank A.G - Custody \\
\hline Pratama Saham & $\begin{array}{l}\text { PT Pratama Capital Assets } \\
\text { Management }\end{array}$ & Deutsche Bank A.G - Custody \\
\hline RD Dana Ekuitas Prima & $\begin{array}{l}\text { PT. Bahana TCW Investment } \\
\text { Managemen }\end{array}$ & Deutsche Bank A.G-Custody \\
\hline Rencana Cerdas & PT. Ciptadana Asset Management & Deutsche Bank A.G - Custody \\
\hline Schroder Dana Istimewa & $\begin{array}{l}\text { PT. Schroder Investment } \\
\text { Management Indonesia }\end{array}$ & HSBC - Custody \\
\hline Schroder Dana Prestasi plus & $\begin{array}{l}\text { PT. Schroder Investment } \\
\text { Management Indonesia }\end{array}$ & HSBC - Custody \\
\hline TRIM kapital & PT. Trimegah Asset Management & CIMB Niaga -Custody \\
\hline
\end{tabular}


Tabel 2

Coefficientsa

\begin{tabular}{|ll|r|r|r|r|r|}
\hline \multirow{2}{*}{ Model } & \multicolumn{2}{|c|}{$\begin{array}{c}\text { Unstandardized } \\
\text { Coefficients }\end{array}$} & \multicolumn{2}{c|}{$\begin{array}{c}\text { Standardized } \\
\text { Coefficients }\end{array}$} & & \\
\cline { 3 - 5 } & & \multicolumn{1}{|c|}{$\mathrm{B}$} & Std. Error & \multicolumn{1}{c|}{ Beta } & \multicolumn{1}{c|}{$\mathrm{t}$} & \multicolumn{1}{c|}{ Sig. } \\
\hline 1 & (Constant) &,- 021 &, 002 & & $-9,438$ &, 000 \\
& Rpt_RFt &, 646 &, 013 &, 808 & 47,933 &, 000 \\
\hline
\end{tabular}

a. Dependent Variable: Rmt_Rft

Tabel 3

\section{Coefficientsa}

\begin{tabular}{|c|c|c|c|c|c|c|}
\hline \multirow{2}{*}{\multicolumn{2}{|c|}{ Model }} & \multicolumn{2}{|c|}{$\begin{array}{l}\text { Unstandardized } \\
\text { Coefficients }\end{array}$} & \multirow{2}{*}{$\begin{array}{c}\begin{array}{c}\text { Standardized } \\
\text { Coefficients }\end{array} \\
\text { Beta } \\
\end{array}$} & \multirow[b]{2}{*}{$t$} & \multirow[b]{2}{*}{ Sig. } \\
\hline & & $\mathrm{B}$ & Std. Error & & & \\
\hline & (Constant) &,- 046 & ,001 & & $-33,850$ &, 000 \\
\hline & Rpt_Rft & ,050 & ,007 & ,352 & 7,574 & ,000 \\
\hline
\end{tabular}

a. Dependent Variable: Rmt_Rft

Tabel 4

Coefficientsa

\begin{tabular}{|c|c|c|c|c|c|c|}
\hline \multirow{2}{*}{\multicolumn{2}{|c|}{ Model }} & \multicolumn{2}{|c|}{$\begin{array}{c}\text { Unstandardized } \\
\text { Coefficients }\end{array}$} & \multirow{2}{*}{$\begin{array}{c}\begin{array}{c}\text { Standardized } \\
\text { Coefficients }\end{array} \\
\text { Beta }\end{array}$} & \multirow[b]{2}{*}{$\mathrm{t}$} & \multirow[b]{2}{*}{ Sig. } \\
\hline & & B & Std. Error & & & \\
\hline & (Constant) &,- 011 & ,002 & & $-6,414$ &, 000 \\
\hline & Rpt_Rft & ,837 & ,023 & ,931 & 36,214 &, 000 \\
\hline
\end{tabular}

a. Dependent Variable: Rmt_Rft

Tabel 5

Coefficientsa

\begin{tabular}{|c|c|c|c|c|c|c|}
\hline \multirow{2}{*}{\multicolumn{2}{|c|}{ Model }} & \multicolumn{2}{|c|}{$\begin{array}{c}\text { Unstandardized } \\
\text { Coefficients }\end{array}$} & \multirow{2}{*}{$\begin{array}{c}\begin{array}{c}\text { Standardized } \\
\text { Coefficients }\end{array} \\
\text { Beta }\end{array}$} & \multirow[b]{2}{*}{$\mathrm{t}$} & \multirow[b]{2}{*}{ Sig. } \\
\hline & & B & Std. Error & & & \\
\hline & (Constant) &,- 034 &, 003 & & $-11,271$ &, 000 \\
\hline & Rpt_Rft &,- 044 & ,043 &,- 100 & $-1,008$ & ,316 \\
\hline
\end{tabular}

a. Dependent Variable: Rmt_Rft 
Tabel 6

Coefficientsa

\begin{tabular}{|rl|r|r|r|r|r|}
\hline \multirow{2}{*}{ Model } & \multicolumn{2}{|c|}{$\begin{array}{c}\text { Unstandardized } \\
\text { Coefficients }\end{array}$} & \multicolumn{2}{c|}{$\begin{array}{c}\text { Standardized } \\
\text { Coefficients }\end{array}$} & & \\
\cline { 3 - 5 } & & \multicolumn{1}{|c|}{$\mathrm{B}$} & Std. Error & \multicolumn{1}{c|}{ Beta } & \multicolumn{1}{c|}{$\mathrm{t}$} & \multicolumn{1}{c|}{ Sig. } \\
\hline 1 & (Constant) &,- 004 &, 002 & & $-1,859$ &, 069 \\
& Rpt_Rft &, 972 &, 037 &, 966 & 26,130 &, 000 \\
\hline
\end{tabular}

a. Dependent Variable: Rmt_Rft

Tabel 7

\section{Coefficientsa}

\begin{tabular}{|c|c|c|c|c|c|c|}
\hline \multirow[b]{2}{*}{ Model } & & \multicolumn{2}{|c|}{$\begin{array}{l}\text { Unstandardized } \\
\text { Coefficients }\end{array}$} & \multirow{2}{*}{$\begin{array}{c}\begin{array}{c}\text { Standardized } \\
\text { Coefficients }\end{array} \\
\text { Beta }\end{array}$} & \multirow[b]{2}{*}{$\mathrm{t}$} & \multirow[b]{2}{*}{ Sig. } \\
\hline & & B & Std. Error & & & \\
\hline & (Constant) & ,098 & ,028 & & 3,491 &, 001 \\
\hline & Rpt_Rft & 2,821 & ,508 & 695 & 5,549 &, 000 \\
\hline
\end{tabular}

a. Dependent Variable: Rmt_Rft

Tabel 8

1 bulanan

Correlations

\begin{tabular}{|ll|r|r|}
\hline & \multicolumn{1}{|c|}{ Kinerja t } & Kinerja t +1 \\
\hline Kinerja t & Pearson Correlation & 1 &, 024 \\
& Sig. (2-tailed) & &, 397 \\
& $\mathrm{~N}$ & 1207 & 1207 \\
\hline Kinerja t +1 & Pearson Correlation &, 024 & 1 \\
& Sig. (2-tailed) &, 397 & \\
& $\mathrm{~N}$ & 1207 & 1207 \\
\hline
\end{tabular}


Tabel 9

\section{3 bulanan}

\begin{tabular}{|ll|r|r|}
\hline \multicolumn{3}{|c}{ Correlations } \\
\hline Kinerja t & Kearson Correlation & 1 &, $119^{*}$ \\
& Sig. (2-tailed) & &, 018 \\
& $\mathrm{~N}$ & 391 & 391 \\
\hline Kinerja t+1 & Pearson Correlation &, $119^{*}$ & 1 \\
& Sig. (2-tailed) &, 018 & \\
& $\mathrm{~N}$ & 391 & 391 \\
\hline
\end{tabular}

*. Correlation is significant at the 0.05 level (2-tailed).

Tabel 10

\section{6 bulanan}

Correlations

\begin{tabular}{|ll|r|r|}
\hline & & Kineria $t+1$ & Kineria t \\
\hline Kinerja t +1 & Pearson Correlation & 1 & -.076 \\
& Sig. (2-tailed) & & .298 \\
& $\mathrm{~N}$ & 187 & 187 \\
Kinerja t & Pearson Correlation & -.076 & 1 \\
& Sig. (2-tailed) & .029 & \\
& $\mathrm{~N}$ & 187 & 187 \\
\hline
\end{tabular}

Tabel 11

1 tahunan

\begin{tabular}{|ll|r|r|}
\multicolumn{4}{|c}{ Correlations } \\
\hline & & \multicolumn{1}{c|}{ Kinerja t } & Kinerja t+1 \\
\hline Kinerja t & Pearson Correlation & 1 &, $482^{* *}$ \\
& Sig. (2-tailed) & &, 000 \\
& $\mathrm{~N}$ & 85 & 85 \\
\hline Kinerja t+1 & Pearson Correlation &, $482^{* *}$ & 1 \\
& Sig. (2-tailed) &, 000 & \\
& $\mathrm{~N}$ & 85 & 85 \\
\hline
\end{tabular}

${ }^{* *}$. Correlation is significant at the 0.01 level (2-tailed). 
Tabel 12

2 tahunan

\section{Correlations}

\begin{tabular}{|ll|r|r|}
\hline & & Kinerja t & Kinerja t+1 \\
\hline Kinerja t & Pearson Correlation & 1 &, $917^{* *}$ \\
& Sig. (2-tailed) & &, 000 \\
& $\mathrm{~N}$ & 34 & 34 \\
\hline Kinerja t+1 & Pearson Correlation &, $917^{* *}$ & 1 \\
& Sig. (2-tailed) &, 000 & \\
& $\mathrm{~N}$ & 34 & 34 \\
\hline
\end{tabular}

${ }^{* *}$. Correlation is significant at the 0.01 level (2-tailed).

\section{Tabel 13 \\ 3 tahunan}

\section{Correlations}

\begin{tabular}{|ll|r|r|}
\hline & & Kinerja t & Kinerja $\mathrm{t}+1$ \\
\hline Kinerja t & Pearson Correlation & 1 &,- 065 \\
& Sig. (2-tailed) & &, 804 \\
& $\mathrm{~N}$ & 17 & 17 \\
\hline Kinerja t+1 & Pearson Correlation &,- 065 & 1 \\
& Sig. (2-tailed) &, 804 & \\
& $\mathrm{~N}$ & 17 & 17 \\
\hline
\end{tabular}


Jurnal Akuntansi Indonesia 